\title{
EFFICIENCY IMPROVEMENT OF GAS TURBINE COGENERATION SYSTEMS
}

\author{
Rabi Karaali, İlhan Tekin Öztürk
}

Original scientific paper

In this study eight methods are evaluated for a gas turbine cogeneration cycle to improve the efficiency. These methods are increasing gas turbine inlet air temperature, cooling the inlet air of the compressor, air preheating, fuel preheating, increasing compressor inlet air pressure, increasing air excess rates, steam injection, and humidification of the inlet air of the compressor. These methods are studied in order to compare their effects on the performance of the systems. The effects of these methods on the exergetic efficiency depend on the kind of the cogeneration cycle. By combining recuperation, preheating fuel and steam injection methods high efficiency can be achieved. The combined methods give the best results under variable heat demands of the market. An appropriate combination of the efficiency improvement methods may increase the exergetic efficiency about $20 \%$. The results show that efficiency improvement methods must be applied together whenever it is possible.

Keywords: cogeneration; efficiency; improvements

Poboljšanje učinkovitosti kogeneracijskih sustava plinske turbine

Izvorni znanstveni članak U radu se procjenjuje osam metoda za poboljšanje učinkovitosti kogeneracijskog ciklusa plinske turbine. Tim se metodama povećava temperatura ulaznog zraka plinske turbine, rashlađuje ulazni zrak kompresora, predgrijava zrak, predgrijava gorivo, povećava tlak ulaznog zraka kompresora, povećava brzina viška zraka, ubrizgava para i vlaži ulazni zrak kompresora. Te se metode istražuju kako bi se usporedilo njihovo djelovanje na performanse sustava. Učinci tih metoda na egzergetsku učinkovitost ovise o vrsti kogeneracijskog ciklusa. Kombiniranjem metoda rekuperacije, predgrijavanja goriva $i$ ubrizgavanja pare može se postići visoka učinkovitost. Kombinirane metode daju najbolje rezultate kod različitih potreba tržišta za toplinom. Odgovarajućom kombinacijom metoda za poboljšanje učinkovitosti može se povećati egzergetska učinkovitost za oko 20 \%. Rezultati pokazuju da se metode za poboljšanje učinkovitosti moraju primijeniti zajedno kada je god to moguće.

Ključne riječi: kogeneracija; poboljšanja; učinkovitost

\section{Introduction}

Cogeneration systems are increasingly used for producing both electricity and heat, with $88 \%$ theoretical cycle efficiency for industry or district heating. Also, some of the exhaust heat energy of cogeneration systems can be used for absorption cooling in summer seasons. Cogeneration systems can work with high capacity and high efficiency nearly all year. Cogeneration systems save $30 \%$ more energy than conventional energy systems $[1,2$, 3]. These power systems produce also less emissions and less $\mathrm{CO}_{2}$. There are various cogeneration systems such as gas turbine, steam turbine, diesel or gas motor and fuel cells. Electric to heat ratio is the most important factor on decision of a cogeneration system. Fuel cell cogeneration systems produce more electricity than other systems and have higher efficiency for electricity production, (approximately $60 \%$ ), but less heat power than other systems $[4,5,6]$. For a cogeneration system, which matched operation conditions best, there are some various methods for improving efficiency at design and operating stages. These methods are reducing auxiliary power consumption, increasing gas turbine inlet air temperature, serving low compressor inlet air temperature, air preheating, fuel preheating, intercooling, increasing compressor inlet air pressure, hydrogen cooled generators, cooling and humidification of the inlet air of the compressor, increasing air excess rates, using advanced gas turbine cooling, steam injection, multiple pressure cycle with reheat and better HRSG design $[1,2,7,8]$.

There are two ways to cool the inlet air of the compressor. First of them is humidification, if the relative humidity is low. The second way is to cool by using a device like a classical chiller or a heat pump or a heat driven absorption system. These two ways depend on the climate of the region of cogeneration systems where they operate. The differences of the compressor inlet air temperature constitute significant changes on the electric power and the thermal energy [9, 10, 11]. Boyce has found that decreasing the compressor inlet air temperature increases the electrical power. For example; the electrical power increases about $13 \div 14 \%$ when the temperature drops from $25^{\circ} \mathrm{C}$ to $0{ }^{\circ} \mathrm{C}$, but the thermal power decreases about $10 \%$ [5]. Kehlhofet, et al., have shown the effects of the compressor inlet air temperature on the relative work of the gas turbine, and cooling the inlet air method increases electricity production for a combined cycle gas-steam turbine power plant [12].

In this study, pulverized water is injected into air at normal conditions $\left(25^{\circ} \mathrm{C}\right.$ and 1 atm. $)$ where the air consists of 12,092 gram vapour $/ \mathrm{kg}$-air in normal conditions and water is injected to obtain saturated air. The amount of injected water into the air is calculated by using the psychometric diagram and the last temperature of the air. Increasing the humidity ratio decreases the molecular weight of the mixture of air-water vapour and that decreases the temperature. On the same issue Ashraf has found similar results of the effects of evaporative cooling on power [8]. Al-Fahed et al., and Amel et al., have found similar result that is, for the simple cogeneration system evaporative cooling increases the efficiency about 2,5\% $[10,13]$.

Compressor inlet pressure (altitude) has important effects on the operating conditions and the performances of the cycles. The altitude increase decreases the air pressure and therefore the working conditions of the cycles are changed for the same exhausts outlet pressure of the cycle. However, if the exhausts outlet pressure of 
the cycle is the same as the inlet air pressure the effect can be negligible. In this study for the sake of the comparison and the reality, the exhausts outlet pressure is taken as $101,3 \mathrm{kPa}$ for all cycles and all working conditions. For that reason decreasing the inlet air pressure has a significant effect on the cycle. Kehlhofet, et al., have given the effect of the altitude on the relative work of the gas turbine and they found that an increase in the altitude from $0 \mathrm{~m}$ (sea level) to $2400 \mathrm{~m}$ relative work of the gas turbine decreases from $100 \%$ to $75 \%$ for a combined cycle gas-steam turbine power plant [12]. Najjar has studied a gas turbine cogeneration plant and found that increasing the compression ratio from 8 to 11 , increases the efficiency of a single cogeneration cycle from $22 \%$ to $55 \%[14]$.

Gas turbine cogeneration cycles have potential to improve energy efficiency and reduce $\mathrm{CO}_{2}$ emissions by applying energy improvement methods and this potential must be used as much as possible $[15,16]$. The present study addressed this point. In this study, the efficiency improving methods of the gas turbine cogeneration systems will be analyzed. The best thing to do at design stage is to define the operating conditions. It is clear that these efficiency improving methods need extra investment, which rises up initial investment. In this study economic assessment will be ignored and only thermodynamic analyses of the cogeneration systems (not multi generation) will be considered and performed. However the thermo-economic optimization and economic assessment of these cycles can be found in the literature $[17,18]$.

\section{Thermodynamic model of the cogeneration systems}

The environmental conditions are considered as $T_{1}=$ $298,15 \mathrm{~K}$ and $P_{0}=101,3 \mathrm{kPa}$. The outlet temperature of the heat recovery steam generator is taken as $400 \mathrm{~K}$ to avoid corrosive sulfuric acid formation in the exhaust. The air compressor flow rate is $\dot{m}_{1}=91,4 \mathrm{~kg} / \mathrm{s}$, the HRSG mass flow rate is $\dot{m}_{\mathrm{s}}=14 \mathrm{~kg} / \mathrm{s}$ saturated steam at 2000 $\mathrm{kPa}$, the power of gas turbine is $30 \mathrm{MW}$, and the flow rate of fuel (methane) is $\dot{m}_{\mathrm{f}}=1,64 \mathrm{~kg} / \mathrm{s}[3,6]$.

The working fluid is assumed to be ideal gas (methane). It is also assumed that cogeneration systems operate at steady state, the combustion is complete and $\mathrm{N}_{2}$ is inert, and the heat loss for the combustion chamber is 2 $\%$ of the fuel's LHV and all other components operate without heat loss. Kinetic and potential energies are ignored. The compressor and turbine operate reversible adiabatic or isentropic [3]. The four cogeneration cycles are shown in Fig. 1.

For the four cogeneration systems steam injection can be applied by using some amount of the steam that is produced by the systems. However, details of the thermoeconomic analyses of steam injected cycles can be found in literature [18].

Compressor outlet, combustion chamber outlet, recuperator exhaust side outlet, heat recovery steam generator inlet, exhaust sides and gas turbine exhaust temperatures are calculated by inserting specific enthalpy expressions for $\mathrm{N}_{2}, \mathrm{O}_{2}, \mathrm{CO}_{2}$ and $\mathrm{H}_{2} \mathrm{O}$ from Bejan et al.
[3]. In addition, the specific entropies of the streams are calculated from the same reference.

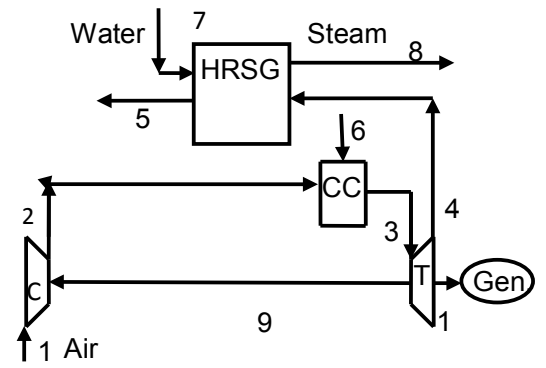

a)

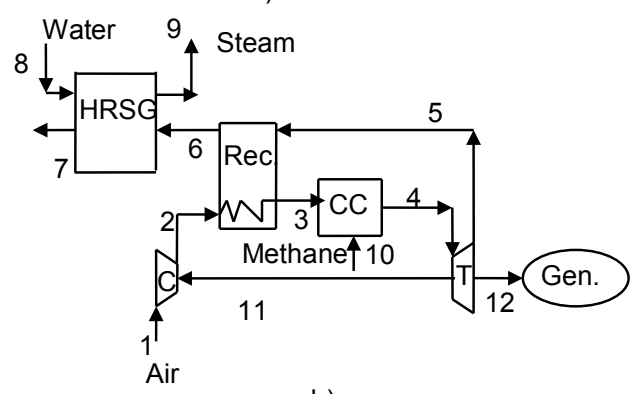

b)

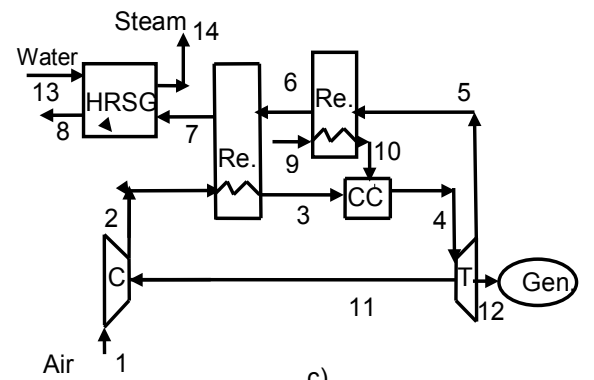

c)

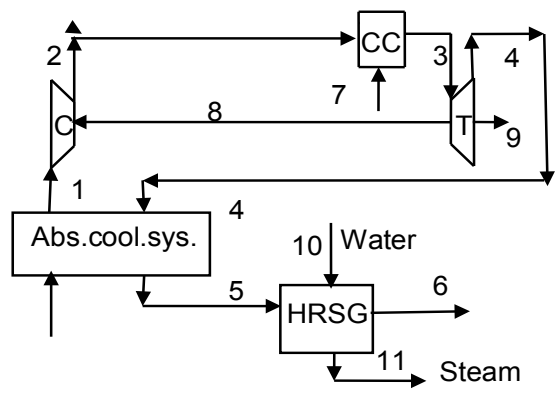

d)

Figure 1 a) Simple (S), b) Air preheated (AP), c) Air-fuel preheated (AFP) and d) Inlet air cooling (IAC) cogeneration systems.

The thermodynamic model, energy and exergy analyses procedure is applied step by step as follows for the air preheated (CGAM) cycle. The functions of the temperature dependent specific enthalpies and, temperature-pressure dependent specific entropies can be found in literature $[3,17]$.

$\bar{h}_{i}=f\left(T_{i}\right)$,

$\bar{s}_{i}=f\left(T_{i}, P_{i}\right)$.

The thermo-physical and chemical exergy could be defined from the following equations [3];

$e=e_{\mathrm{ph}}+e_{\mathrm{ch}}$ 
$e_{\mathrm{ch}}=\left(\sum x_{k} \bar{e}_{k}{ }^{\mathrm{ch}}+\bar{R} T_{0} \sum x_{k} \ln x_{k}\right)$,

$e_{\mathrm{ph}}=h-h_{0}-T_{0}\left(s-s_{0}\right)$.

The relations of the air preheated cycle equipments can be given as follows:

$\dot{W}_{\mathrm{C}}=\dot{m}_{1}\left(h_{2}-h_{1}\right)$.

Exergy balance for compressor could be written as,

$\dot{E}_{\mathrm{D}, \mathrm{C}}=\dot{E}_{1}-\dot{E}_{2}+W_{\mathrm{C}}$.

Exergetic efficiency of the air compressor can be calculated as,

$\eta_{\mathrm{ex}, \mathrm{C}}=\frac{\dot{E}_{2}-\dot{E}_{1}}{\dot{W}_{\mathrm{C}}}$.

Exergy balance equation can be written for recuperator as,

$\dot{E}_{\mathrm{D}, \mathrm{R}}=\dot{E}_{2}-\dot{E}_{3}+\dot{E}_{5}-\dot{E}_{6}$. as,

Exergetic efficiency of the recuperator can be written

$\eta_{\mathrm{ex}, \mathrm{R}}=\frac{\dot{E}_{3}-\dot{E}_{2}}{\dot{E}_{5}-\dot{E}_{6}}$.

The chemical reaction in the combustion chamber can be written as follows [3];

$\bar{\lambda} \cdot \mathrm{CH}_{4}+\left(0,7748 \cdot \mathrm{N}_{2}+0,2059 \cdot \mathrm{O}_{2}+0,0003 \cdot \mathrm{CO}_{2}+0,019 \cdot \mathrm{H}_{2} \mathrm{O}\right) \rightarrow$ $(1+\bar{\lambda}) \cdot\left(X_{\mathrm{N}_{2}} \mathrm{~N}_{2}+X_{\mathrm{O}_{2}} \mathrm{O}_{2}+X_{\mathrm{CO}_{2}} \mathrm{CO}_{2}+X_{\mathrm{H}_{2} \mathrm{O}} \mathrm{H}_{2} \mathrm{O}\right)$ as

Heat loss of the combustion chamber can be written

$$
\dot{Q}_{\text {loss,CC }}=0,02 \dot{m}_{\text {fuel }} L H V_{\mathrm{CH}_{4}} \text {. }
$$

Energy balance equation of the combustion chamber can be given as,

$\dot{m}_{3} h_{3}+\dot{m}_{10} h_{10}=\left(\dot{m}_{3}+\dot{m}_{10}\right) h_{4}+\dot{Q}_{\mathrm{loss}, \mathrm{CC}}$

The enthalpy named $h_{10}$ consists of the value of $L H V$ and the enthalpy of fuel gas. Exergy balance equation can be written for combustion chamber as,

$\dot{E}_{\mathrm{D}, \mathrm{CC}}=\dot{E}_{3}+\dot{E}_{10}-\dot{E}_{4}$.

Exergetic efficiency of the combustion chamber is,

$\eta_{\mathrm{ex}, \mathrm{CC}}=\frac{\dot{E}_{4}}{\dot{E}_{3}+\dot{E}_{10}}$.
Work obtained from the gas turbine,

$\dot{W}_{\text {net, } \mathrm{T}}=\dot{m}_{4}\left(h_{5}-h_{4}\right)-\dot{W}_{\mathrm{C}}$

Energy and exergy balance equations of the gas turbine are [16],

$$
\begin{aligned}
& \dot{m}_{4} h_{4}=\dot{m}_{5} h_{5}+\dot{W}_{\mathrm{C}}+\dot{W}_{\text {net } \mathrm{T}}, \\
& \dot{E}_{\mathrm{D}, \mathrm{T}}=\dot{E}_{4}-\dot{E}_{5}-\dot{W}_{\mathrm{C}}-\dot{W}_{\mathrm{T}} .
\end{aligned}
$$

Exergetic efficiency of the gas turbine is,

$$
\eta_{\mathrm{ex}, \mathrm{T}}=\frac{\dot{W}_{\mathrm{net}, \mathrm{T}}+\dot{W}_{\mathrm{C}}}{\dot{E}_{4}-\dot{E}_{5}} .
$$

Exergy balance equation for the heat recovery steam generator can be written as,

$\dot{E}_{\mathrm{D}, \mathrm{HRSG}}=\dot{E}_{6}-\dot{E}_{7}+\dot{E}_{8}-\dot{E}_{9}$

Exergetic efficiency of the heat recovery steam generator is,

$\eta_{\mathrm{ex}, \mathrm{HRSG}}=\frac{\dot{E}_{9}-\dot{E}_{8}}{\dot{E}_{6}-\dot{E}_{7}}$

For the absorption cycle $C O P$ is taken as for $\mathrm{LiBr}$ $\mathrm{H}_{2} \mathrm{O}$, with $C O P=0,70$.

The overall energy balance of the systems is [3],

$m_{1} h_{1}+\dot{m}_{10} L H V_{\mathrm{CH}_{4}}-\dot{Q}_{\text {loss, } \mathrm{CC}}-\dot{m}_{7} h_{7}-\dot{W}_{\text {net }, \mathrm{T}}-$
$-\dot{m}_{8}\left(h_{8}-h_{9}\right)=0$.

Exergetic efficiency of the air preheated cycle is,

$\eta_{\mathrm{ex}}=\frac{\dot{W}_{\mathrm{net}, \mathrm{T}}+\left(\dot{E}_{9}-\dot{E}_{8}\right)}{\dot{E}_{10}}$.

\section{The results and discussion}

The results of efficiency improvement analysis of gas turbine cycle are presented in Figs. $2 \div 8$. In Fig. 2, variations of exergetic efficiency with different compressor inlet air temperatures for the simple $(\mathrm{S})$, the air (AP), and the air-fuel preheated (AFP) cogeneration cycles.

The exergy efficiency of the systems decreases with the increasing inlet air temperature because more power is consumed for compressing the intake air. For the simple cycle (S), this loss is less than the air (AP) and the air-fuel (AFP) preheated cycles. Simple cycle has the lowest exergy efficiency and air-fuel preheated cycle has the highest exergy efficiency.

It can be seen in Fig. 3 that decreasing the compressor inlet air temperature and increasing excess air rates increases the exergy efficiency of the air and the airfuel preheated cycles. For the simple cycle the exergy 
efficiency reaches the maximum value for the excess air rates around 2,5 and then decreases.

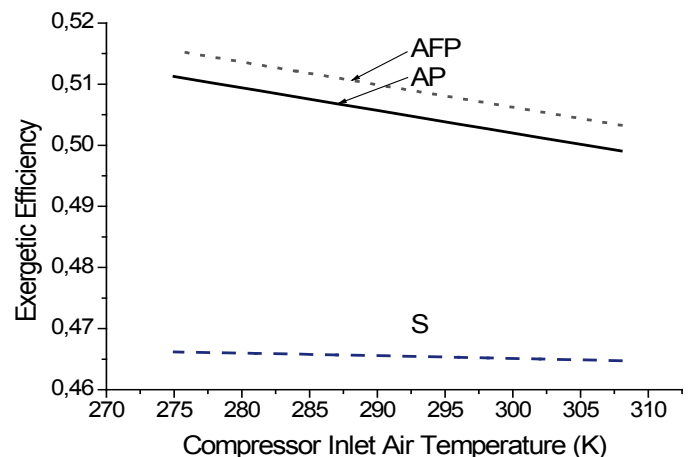

Figure 2 Variations of exergetic efficiency with different compressor inlet air temperatures

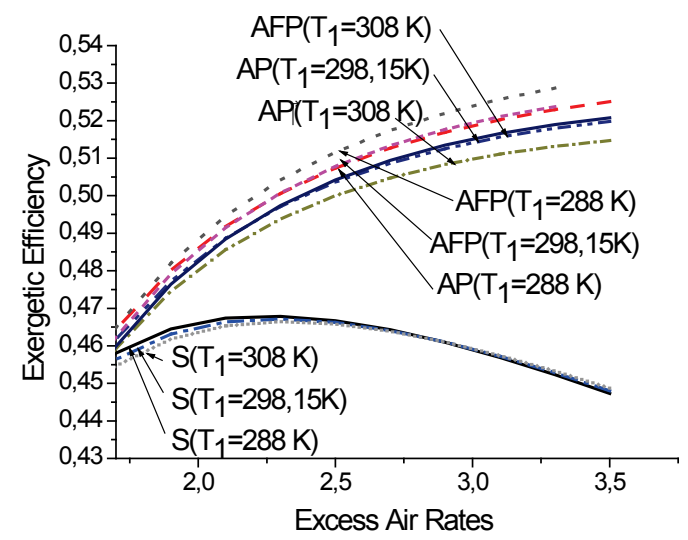

Figure 3 Variations of exergetic efficiency with different compressor inlet air temperatures and with different excess air rates.

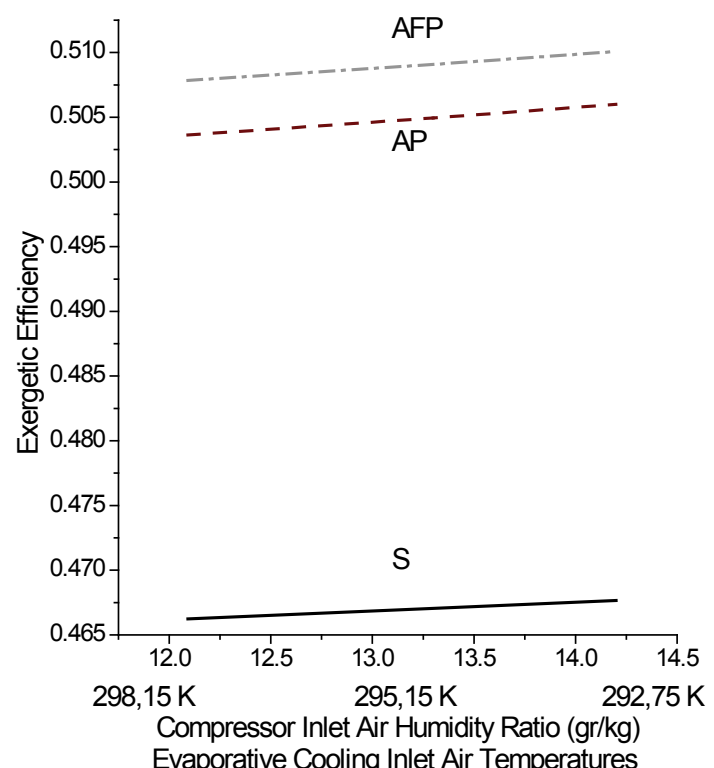

Figure 4 Variations of exergetic efficiency with different compressor inlet air humidity ratios

It can be seen in Fig. 4 that increasing the specific humidity of the compressor inlet air increases the exergy efficiency of the systems. In Fig. 5 it is found that increasing altitude decreases the exergy efficiency because of less power obtained from the gas turbine.

In Fig. 6 variations of energy and exergy efficiencies with different compression ratios are given. For that calculation the outlet temperature of the combustion chamber is fixed (taken constant) and the recuperator air side outlet temperature is kept constant at $7 \div 15 \mathrm{~K}$ below the turbine exhaust outlet temperature. Increasing compression ratios increases energy efficiency of the air and the air-fuel cycles, but decreases the exergetic efficiency.

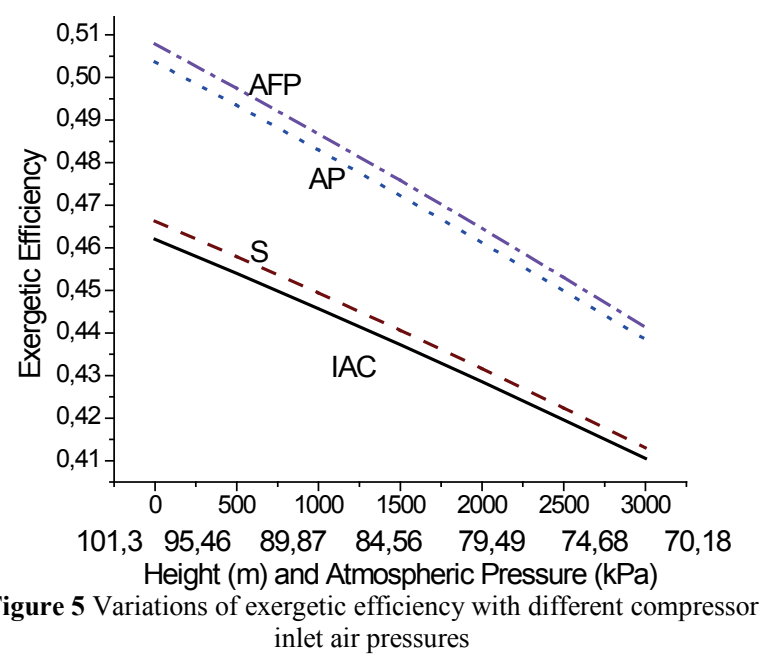

In Fig. 7 variations of exergy efficiency with excess air rates for different compression ratios are given. For the simple and the inlet air cooling cycles maximum efficiencies are obtained for approximately $2 \div 2,5$ excess air rates and for high compression rates $(r=16)$. For the air and the air-fuel preheated cycles maximum efficiencies are obtained for high excess air rates and for high compression rates $(r=16)$. In Fig. 7 some of the curves are cut because the system was reached to the boundary conditions. It is found that the air-fuel preheated cycle is the most efficient cycle among the four cycles. In all cycles maximum efficiencies are obtained at high compression ratios $(r=16)$.

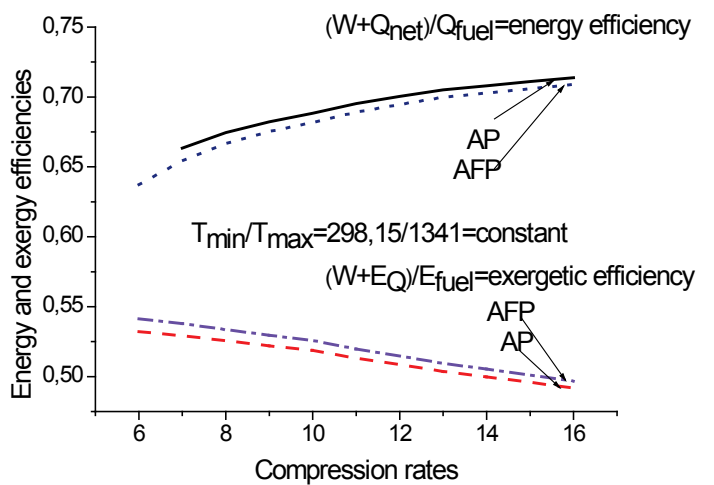

Figure 6 Variations of energy and exergy efficiencies with different compression rates

In Fig. 6 it can be seen that taking the combustion outlet temperature as constant, the exergetic efficiency decreases for high compression ratios. However, in Fig. 7 the combustion outlet temperature is not constant and is increasing with high compression ratios. The reason is that increasing the combustion outlet temperature increases the exergetic efficiency. That means that the combustion outlet temperature is more effective on the exergetic efficiency than the compression ratios. 
In Fig. 8 variations of exergy efficiencies with injected steam mass rates for different compression ratios are given. It can be seen that in high compression ratios increasing injected steam mass decreases the exergetic efficiencies of the cycles except the simple cycle in low compression ratios. Steam mass injection decreases the outlet temperature of the combustion chamber. The steam mass injection method also decreases the heat power however increases the electric power of the cycles. A slight increase is seen in the simple cycle in low compression ratios which can be explained that increase in electric power is more effective than the low temperature heat power. However steam injection prevents the formations of $\mathrm{NO}_{x}$.

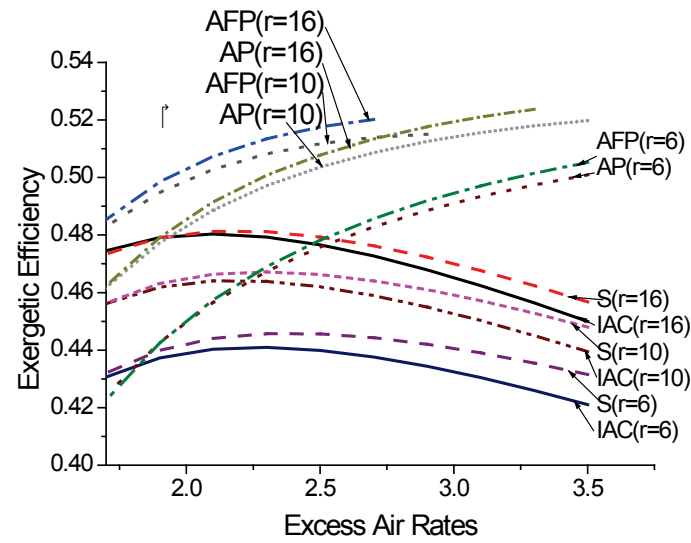

Figure 7 Variations of exergy efficiency with excess air rates for different compression rates

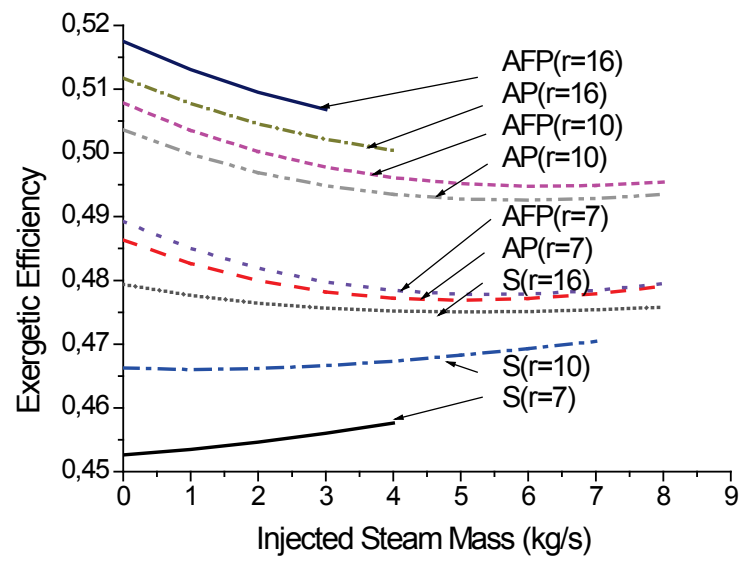

Figure 8 Variations of exergy efficiencies with injected steam mass for different compression rates

In the literature various methods are applied to the gas turbine cogeneration cycles to improve the efficiency. The most effective methods are optimization, reducing auxiliary power consumption, increasing gas turbine inlet air temperature, air preheating, fuel preheating, intercooling, increasing compressor inlet air pressure, hydrogen cooled generators, cooling of the inlet air of the compressor, humidification of the inlet air of the compressor, increasing air excess rates, advanced gas turbine cooling, steam injection, multiple pressure cycle with reheat and better HRSG design $[1,2,7,8]$.

Fifteen of the efficiency improving methods and their approximate effects on overall exergy efficiency are given in Tab. 1. It can be seen that the most effective exergy efficiency improving methods are optimization, increasing air excess rates, air preheating, increasing gas turbine inlet air temperature, and increasing compressor inlet air pressure methods. Optimization method is also the cheapest methods among other exergy efficiency improving methods.

Table 1 Exergy efficiency improving methods and their approximate effects on the overall efficiency $[1,2,3,4,5,6,7]$

\begin{tabular}{|l|c|}
\hline \multicolumn{1}{|c|}{ Exergy efficiency improving method } & $\%$ \\
\hline Increasing gas turbine inlet air temperature & $1 \div 8$ \\
\hline Air preheating & $3 \div 8$ \\
\hline Fuel preheating & $1 \div 3$ \\
\hline High compressor inlet air pressure & $3 \div 10$ \\
\hline Steam injection (effective for electric eff.) & $1 \div 2$ \\
\hline Humidification of the inlet air of the compressor & $0,5 \div 5$ \\
\hline Cooling of the inlet air of the compressor & $0,5 \div 2$ \\
\hline Increasing air excess rates & $1 \div 8$ \\
\hline Intercooling & $1 \div 5$ \\
\hline Advanced gas turbine cooling & $1 \div 6$ \\
\hline Multiple pressure cycle with reheat & $1 \div 6$ \\
\hline Hydrogen cooled generators & $1 \div 2$ \\
\hline Better HRSG design & $1 \div 5$ \\
\hline Optimization & $4 \div 15$ \\
\hline Reducing auxiliary power consumption & - \\
\hline
\end{tabular}

In this study eight methods, which are used for boosting the exergy efficiency of a gas turbine cogeneration cycle were analysed. These methods which are in Tab. 1, are increasing gas turbine inlet air temperature, cooling the inlet air of the compressor, air preheating, fuel preheating, increasing compressor inlet air pressure, increasing air excess rates, steam injection, and humidification of the inlet air of the compressor. The effects of these methods on the exergetic efficiency depend on the kind of the cogeneration cycle.

The results of this study are in good agreement with the literature as it is summarized in the following;

- The maximum efficiency is obtained for the air-fuel preheated cycle. The second, third and fourth efficient ones are obtained for the air preheated, the simple, and the inlet air cooling cycles, respectively.

- The exergetic efficiencies of the air-fuel preheated and the air preheated cycles are slightly different from each other. Also the exergetic efficiencies of the simple and the inlet air cooling cycles are slightly different from each other. The exergetic efficiencies of the air-fuel preheated and the air preheated cycles are approximately $8 \%$ higher than the simple and the inlet air cooling cycles.

- Decreasing compressor inlet air temperature increases the exergetic efficiency of the cycles. This efficiency increase of the air-fuel and the air preheated cycles is better than the simple cycle.

- The maximum exergetic efficiency is obtained for 2,5 excess air rate for the simple cycle. For the air-fuel and the air preheated cycles the maximum efficiency is obtained at 3,5 excess air rates.

- Increasing the inlet air humidity ratio by evaporative cooling increases the exergetic efficiency of the cycles between 0,5 to $5 \%$.

- Increasing the altitude of the cycles from sea level (or decreasing compressor inlet air pressure) decreases the exergetic efficiency of the four cycles up to $20 \%$. 
- Increasing the compression ratio for constant combustion chambers outlet temperatures decreases the exergetic efficiency of the four cycles. However increasing the combustion chambers outlet temperatures increase the exergetic efficiencies of the four cycles. It can be concluded that the combustion outlet temperature is more effective on the exergetic efficiency than the compression ratios. Also it can be concluded that increasing the compression ratios increases the combustion outlet temperature so that it increases the exergetic efficiency.

- Steam injection method is efficient at low heat and high electric power demand situations. But this method is limited with $19 \%$ of the air-steam rate. Steam injection method increases the electric production efficiency but decreases the heat production efficiency and the total exergetic efficiency of the cycles. However, steam injection increases exergetic efficiency in low compression ratios of the simple cycle.

- For the efficiency, the heat of the system should not be used for cooling inlet air of the compressor if there is not demand for cooling outside the system. By injecting (spraying) water into inlet air of the compressor (humidification) or by using waste heat to drive the absorption system cooling can be achieved. Especially at summer application of humidification (spraying water) method can improve efficiency of the system about $5 \%$.

- Combining the methods of recuperation, preheating the fuel and steam injection achieved very high efficiency.

- As it is reported in the literature [1 to 7] using multi stage compression with inter cooling, multi stage turbines with reheat combustor and increasing recuperator outlet temperature and increasing isentropic efficiencies of the compressor and the turbine increases the exergetic efficiency.

- For designing a cogeneration cycle, the parameters that affect the exergetic efficiency should be taken into consideration. Also an optimization procedure of the designed cycle is crucial.

\section{Conclusions}

In this study, some efficiency improvement methods that are applied on a simple cogeneration system were analysed. The results of each method are in good agreement with the literature. The methods are, namely, increasing gas turbine inlet air temperature, cooling the inlet air of the compressor, air preheating, fuel preheating, high compressor inlet air pressure, increasing air excess rates, steam injection, and humidification of the inlet air of the compressor. The effects of these methods on the exergetic efficiency depend on the kind of the cogeneration cycle. Combining the methods of recuperation, preheating fuel and steam injection achieved very high efficiency. For variable heat demands (vapour or hot water) of the market it gives the best results. Combining the efficiency improvement methods appropriately may increase the exergetic efficiency about $20 \%$.

\section{Conflict of Interests}

The authors declare that there is no conflict of interests regarding the publication of this paper. The authors do not have any direct financial relation with any commercial identity, supporting grants, or any other entity for their paper.

\section{Nomenclature}

$\begin{array}{ll}A P & \text { air preheated cycle } \\ A F P & \text { air-fuel preheated cycle } \\ C O P & \text { coefficient of performance } \\ e & \text { specific exergy }(\mathrm{kJ} / \mathrm{kg}) \\ \dot{E} & \text { exergy flow rate }(\mathrm{kW}) \\ h & \text { specific enthalpy }(\mathrm{kJ} / \mathrm{kg}) \\ \text { IAC } & \text { inlet air cooling cycle } \\ L H V & \text { lower heating value }(\mathrm{kJ} / \mathrm{kg}) \\ \dot{m} & \text { mass flow rate }(\mathrm{kg} / \mathrm{s}) \\ P & \text { pressure }(\mathrm{kPa}) \\ \dot{Q} & \text { heat flow rate }(\mathrm{kW}) \\ \mathrm{S} & \text { simple cycle } \\ S & \text { specific entropy }(\mathrm{kJ} / \mathrm{kgK}) \\ T & \text { temperature }(\mathrm{K}) \\ \dot{W} & \text { power }(\mathrm{kW}) \\ x_{i} & \text { molar fraction }\end{array}$

\section{Greek letters}

$\begin{array}{ll}\eta & \text { efficiency } \\ \lambda & \text { constant }\end{array}$

\section{Subscripts}

$\begin{array}{ll}\text { C } & \text { compressor } \\ \text { CC } & \text { combustion chamber } \\ \text { ch } & \text { chemical } \\ \text { D } & \text { destruction } \\ \text { ex } & \text { exergy } \\ \text { HRSG } & \text { heat recovery steam generator } \\ \text { ph } & \text { physical } \\ \text { R } & \text { recuperator } \\ \text { T } & \text { turbine } \\ 0 & \text { environment conditions }\end{array}$

\section{References}

[1] Karaali, R. Thermoeconomic optimization of cogeneration power plants. PhD Thesis. Kocaeli Univ. 2010

[2] Horlock, J. H. Cogeneration-combined heat and power (CHP). CRİEGER Pub. 1997.

[3] Bejan, A.; Tsatsaronis, G.; Moran, M. Thermal design and optimization. Wiley Pub. 1996.

[4] Cogeneration Systems and Engine and Turbine Drives.// ASHRAE Systems and Equipment Handbook (SI), Chapter 7 / American society of Heating, Refrigerating and air conditioning Engineers ASHRAE, New York 2000.

[5] Boyce, M. P. Handbook for cogeneration and combined cycle power plants. Asme Press, 2002, pp. 42-220.

[6] Moran, J. M.; Tsatsaronis, G. The CRC handbook of thermal engineering. CRC Press LLC, 2000, pp. 15-109.

[7] Jaluria, Yogesh. Design and optimization of thermal systems. CRC Press, 2008. 
[8] Ashraf, M. B. Effects of evaporative inlet and aftercooling on the recuperated gas turbine cycle // Applied Thermal Engineering. 21(2001), pp. 1875-1890. DOI: 10.1016/S13594311(01)00054-0

[9] Paepe, D. M.; Dick, E. Technological and economical analysis of water recovery in steam injected gas turbine // Applied Thermal Engineering. 21, 2(2001), pp. 135-156. DOI: 10.1016/S1359-4311(00)00029-6

[10] Al-Fahed, S. F.; Alasfour, F. N.; Abdulrahim, H. K. The effect of elevated inlet air temperature and relative humidity on cogeneration systems. // International Journal of Energy Research. 33(2009), pp. 1384-1394. DOI: 10.1002/er.1552

[11] Santo, D. B. E.; Gallo, W. L. R. Predicting performance of a gas turbine cogeneration system with inlet air cooling.// Ecos2000 Proceedings / Universiteit Twente, Nederland. 2000

[12] Kehlhofet, R.; Bachmann, R.; Nielsen, H.; Warner, J. Combined cycle gas steam turbine power plants. Penwell P. C., 1999.

[13] Amel, A. A; Cadavid, F. J. Influence of the relative humidity on the air cooling thermal load in gas turbine power plant. // Applied Thermal Engineering. 22(2002), pp. 1529-1533. DOI: 10.1016/S1359-4311(02)00063-7

[14] Najjar, Y. S. H. Comparison of performance for cogeneration systems using single or twin shaft gas turbine engines. // Applied Thermal Engineering. 17, 2(1997), pp. 113-124. DOI: 10.1016/S1359-4311(96)00028-2

[15] Bilgen, E. Exergetic and engineering analyses of gas turbine based cogeneration systems. // Energy. 25, 12(2000), pp. 1215-1229. DOI: 10.1016/S0360-5442(00)00041-4

[16] Lucas, K. On the thermodynamics of cogeneration. // Int. J. Therm. Sci. 39, 9-11(2000), pp. 1039-1046.

[17] Karaali, Rabi; Öztürk, İlhan Tekin. Thermoeconomic optimization of gas turbine cogeneration plants. // Energy. 80 (2015), pp. 474-485. DOI: 10.1016/j.energy.2014.12.004

[18] Karaali, Rabi; Öztürk, İlhan Tekin. Thermoeconomic analyses of steam injected gas turbine cogeneration cycles // ACTA Physica Polonica A. 128, 2B, (2015), p: B279B281.

\section{Authors' addresses}

Rabi Karaali, Assist. Prof. Dr.

Department of Mechanical Engineering, Bayburt University, 69000 Bayburt, Turkey

E-mail: rabikar@gmail.com

\section{Illhan Tekin Öztürk, Prof. Dr.}

Department of Mechanical Engineering, Kocaeli University,

Umuttepe Campus, 41380 Kocaeli, Turkey

E-mail: ilhan@kou.edu.tr 